\title{
POST-POSTMODERN CINEMA AT THE TURN OF THE MILLENNIUM: PAUL THOMAS ANDERSON'S MAGNOLIA
}

\author{
JESÚS BOLAÑO QUINTERO \\ Universidad de Cádiz \\ jesus.bolano@uca.es
}

Received: 20 May 2020

Accepted: 26 July 2020

\section{KEYWORDS}

Magnolia; Paul Thomas Anderson; post-postmodern cinema; New Sincerity; French New Wave; Jean-Luc Godard; Vivre sa Vie

\section{PALABRAS CLAVE}

Magnolia; Paul Thomas Anderson; cine post-postmoderno; Nueva Sinceridad; Nouvelle Vague; Jean-Luc Godard; Vivir su vida

\begin{abstract}
Starting with an analysis of the significance of the French New Wave for postmodern cinema, this essay sets out to make a study of Paul Thomas Anderson's Magnolia (1999) as the film that marks the beginning of what could be considered a paradigm shift in American cinema at the end of the 20th century. Building from the muchdebated passing of postmodernism, this study focuses on several key postmodern aspects that take a different slant in this movie. The film points out the value of aspects that had lost their meaning within the fiction typical of postmodernism-such as the absence of causality; sincere honesty as opposed to destructive irony; or the loss of faith in Lyotardian meta-narratives. We shall look at the nature of the paradigm shift to link it to the desire to overcome postmodern values through a recovery of Romantic ideas.
\end{abstract}

\section{RESUMEN}

Partiendo de un análisis del significado de la Nouvelle Vague para el cine postmoderno, este trabajo presenta un estudio de Magnolia (1999), de Paul Thomas Anderson, como obra sobre la que pivota lo que se podría tratar como un cambio de paradigma en el cine estadounidense de finales del siglo XX. El estudio parte de la muy discutida muerte del postmodernismo para centrarse en varios aspectos clave postmodernos que toman un cariz diferente en este filme. En este filme se ponen en valor aspectos que habian perdido sentido dentro de la ficción propia del postmodernismo-como la 
ausencia de causalidad, la ironía contrapuesta a una honestidad sincera, o la perdida de fe en las metanarrativas lyotardianas-. Se pretende arrojar luz sobre la naturaleza del cambio de paradigma para ligarlo al deseo de superar el postmodernismo a través de ideas propias del Romanticismo.

\section{INTRODUCTION}

The terrorist attacks of September 11, 2001 marked the symbolic beginning of a new era. However, the controversial debate about the decline of postmodernism and the configuration of a new kind of modernity had already been going on for quite some time. This debate in the world of theory had a materialist correlate in the world of art and creative fiction. One of the first authors to detect the shortcomings of the cultural phase of the second half of the 20th century and offer a plausible alternative was David Foster Wallace. In his works of fiction and non-fiction, he offered a solution to the feelings of solipsism, nihilism and existentialism brought about by decades of postmodern relativism: a writing of sincerity and honesty. Among the literary "peers and inheritors", as Adam Kelly called them in "David Foster Wallace and New Sincerity Aesthetics," are Dave Eggers, Michael Chabon, Mark Z. Danielewski, Jonathan Safran Foer, Jennifer Egan, Tom McCarthy or Zadie Smith. In the field of cinema, this new trend was reflected in the works of directors as Wes Anderson, Charlie Kaufman, Jonathan Dayton, Valerie Faris, Spike Jonze or Paul Thomas Anderson. With this in mind, this article analyses Anderson's film Magnolia in the context of this postpostmodern paradigm shift of the turn of the millennium. Our premise is that this film acts as an entryway into the next cultural phase. It can be regarded as a cinematographic hybrid, as it starts appealing for the complicity of a postmodern audience that, very soon into the film, see how their expectations for relativistic detachment through irony are shattered and transformed into a sincere sympathy towards the characters' suffering. In order to situate the theoretical framework from which this film starts, this article begins with an analysis of Jean Luc Godard's Vivre sa vie: film en douze tableaux with the purpose of ascertaining the significance of the French New Wave for postmodern cinema. This will provide the postmodern cinematographic vantage of relativism from which Magnolia starts. In the same way as Vivre sa vie symbolizes the 
liminal postmodernism of the French New Wave, Anderson's film represents the liminal post-postmodernism of American cinema.

\section{THE LIMINAL POSTMODERNISM OF THE FRENCH NEW WAVE}

The modernist experimentation of the directors of the French New Wave leads to postmodern self-referentiality. Vivre sa vie: film en douze tableaux, directed by Jean-Luc Godard, premiered in 1962 and, we could argue, this film opens the door to postmodernism. As Shun-Liang Chao indicates in his article "(Post)Modern Godard: Vivre sa vie" (2005), "some of the innovations in Vivre sa vie open the gate to postmodern aesthetics." In order to shed some light on this, we are going to focus on one of the sequences of this film. Nana, a Parisian girl who leaves her family to be an actress and who ends up as a prostitute, meets a philosopher in a café and has a conversation with him. The actor who played this role is Brice Parain, a French philosopher and essayist who devoted himself to the study of the nature of language. While they speak, they unravel the essential themes that, even today, are at the centre of the discussions on the current shift of cultural phase. The conversation begins when Nana comments on the impossibility of expressing with words what she thinks. The philosopher makes her understand that, although language cannot represent the truth, this is the only way we have to communicate. In this regard, he says: "I was always impressed that you cannot live without speaking." This film, which moves between modernism and postmodernism, precedes the subsequent cinematographic tradition and shows, in a hybrid format, the essence of language-of course, this would later be developed in Jean-François Lyotard's The Postmodern Condition: A Report on Knowledge (1979), with a theoretical intention. The structure of the film itself, as Susan Sontag assures in "Godard's Vivre sa vie" (1964), does not have a causal meaning, it explains absolutely nothing, and there is no cause and effect relationship:

The whole point of Vivre sa vie is that it does not explain anything. It rejects causality. (Thus, the ordinary causal sequence of narrative is broken in Godard's film by the extremely arbitrary decomposition of the story into twelve episodes-episodes which are serially, rather than causally, related). (220)

Following in that vein, in the conversation, Parain makes clear that the obvious link between entropy and the volatilealthough inescapable-connection relating thought and language, 
leads to a reflection on the nature of truth. It calls for an effort towards a more correct use of the language through a versed knowledge of it. This knowledge, which is also linked to aesthetics, carries Wittgensteinian reminiscences, as we can read in the point 4.003 of Wittgenstein's Tractatus Logico-Philosophicus:

Most propositions and questions, that have been written about philosophical matters, are not false, but senseless. We cannot, therefore, answer questions of this kind at all, but only state their senselessness. Most questions and propositions of the philosophers result from the fact that we do not understand the logic of our language. (39)

To speak well is to look at life with detachment, affirms the philosopher. This could be related to what Tim Vermeulen and Robin van den Akker indicate in their now seminal article "Notes on Metamodernism" (2010): an oscillation must be produced in order to solve the problems that cause both total disaffection with reality and enthusiasm for it. They argue that postmodernism, which has ended coinciding with the turn of the millennium, is being replaced by a sensibility that ranges from "a modern enthusiasm to a postmodern irony," that is, between the detachment that Parain refers to and the attachment of the pre-wittgensteinian concept of reality. They call this new sensibility "metamodernism." Following this argumentation, Parain says the following about silence and words: "We oscillate between the two because it's the movement of life [...] from everyday life one rises to a life... we may call superior [...] it is the life of thought. However, this life of thought presupposes one has killed the everyday life, the life that is too elementary" ${ }^{1}$ (all translations from the film, my own). The problem of living in the "superior life," as the philosopher says, without an escape valve, is that the connection with an immanent reality is abandoned, which makes us lose critical sense. That escape valve is the oscillation that Vermeulen $\&$ van den Akker talk about in their article "Notes on Metamodernism."

The result of all this may become fundamentalism. That is one of the fears in the current paradigm shift, as we will see.

\footnotetext{
1 "On balance entre les deux parce que c'est un... c'est le mouvement de la vie, qui est, qui... on est dans la vie quotidienne et puis on s'en élève vers une vie... appelons-la supérieure, c'est pas bête de le dire, parce que c'est la vie avec la pensée, quoi. Mais cette vie avec la pensée suppose qu'on a tué la vie quotidienne, la vie trop élémentaire."
} 
However, one cannot stop looking for a transcendence for fear of totalitarianism or of repeating history. In this regard, Nana makes the following comment: "Someone told me once: "the truth is in everything, even in the error,"'2 to what Parain replies that, in effect, German philosophy serves to redirect us to life-from which language have separated us-, and "to know how to accept that one must go through error to arrive at the truth." 3 Nowadays, however, that oscillation must serve to revise historical errors without fear. We will see how Magnolia shares this view in order to construct a postpostmodern alternative.

Interestingly, the titles of Godard's latest two full-length films to date are Adieu au langage (2014) and Le livre d'image (2018)-they were translated into English as Goodbye to Language and The Image Book. Both titles appeal to communication without words. In the first of these, the director calls for the recovery of memory, of the past (in which mistakes have been made), the same concept that Parain refers to in Vivre sa vie. Along with images from World War II, in this film there are passages in which a transcendental Romanticism is recovered through the figures of Mary Shelley and Lord Byron. Saying goodbye to language is the only solution, it is the only way to end relativism, even if it means running the risk of making the same mistakes again. In the film, Godard tells us that the word that the Apaches used for the world was "forest." This is reminiscent of Herder's idea of Ursprache, which is linked to American transcendentalism. Thus, post-postmodernism is placed in direct connection with Romanticism, and even with American transcendentalism, alluding to a pristine monistic language loaded with referentiality and essentialism.

In "Notes on Metamodernism," Vermeulen and van den Akker highlight the term "quirky cinema," coined by James MacDowell and developed in his article "Notes on Quirky" (2010), as an example of their proposal for a new oscillating sensibility. This type of cinema could be included in the New Sincerity movement-term coined by Adam Kelly in his article "David Foster Wallace and the New Sincerity in American Fiction" (2010) to designate the new drift that fiction took at the turn of the millennium, which was represented in the figure of the writer David Foster Wallace. Quirky cinema is

2 "Une fois quelqu'un m'a dit 'la vérié est en tout et même un peu dans l'erreur."

3 “[à] savoir nous faire accepter qu'il faut passer par l'erreur pur arriver à la vérité." 
defined as a reaction to a type of films denominated "smart," a term popularized by Jeffrey Sconce in his article "Irony, Nihilism and the New American 'smart' Film" (2002). Sconce names filmmakers Todd Solondz, Neil LaBute or Alexander Payne as representatives. ${ }^{4}$ Some of the directors that Sconce names as members of this type of cinema, such as Spike Jonze or Wes Anderson, will later be part of the quirky cinema movement. The characteristics of smart cinema are the opposite of those of the next generation of American filmmakers and the New Sincerity: irony, dark humour, fatalism, relativism and nihilism-words usually used to list the characteristics and consequences of postmodernism. Quirky cinema, which is representative of the change, as it has the characteristics of the new cultural phase at the turn of the millennium, responds to smart cinema trying to redeem the nihilistic apathy in which the protagonists of the films of the previous movement operate. The difference between these two styles lies, says MacDowell-in the same way as with the New Sincerity movement-in the way in which irony is used. Like metamodernism, this type of cinema opts for the oscillation between irony and honesty.

Ultimately, all these elements help construct what is perhaps the most distinctive characteristic of the quirky: a tone that exists on a knife-edge of judgment and empathy, detachment and engagement, irony and sincerity. (13)

MacDowell refers to the use of irony that Sconce attributes to smart cinema by opposing it to sincerity: "irony [...] is opposed to 'sincerity,' 'positivity,' and the opposite corollaries of the words singled out above: 'engagement,' 'passion,' 'affect,' and so on" (11). The oscillation between sincerity and irony responds to the feeling of

\footnotetext{
4 "Such cinema has many variations the arch emotional nihilism of Solondz in Storytelling (2001), Happiness and Welcome to the Dollhouse (1995), and of LaBute in Your Friends and Neighbors and In the Company of Men (1997), Alexander Payne's 'blank' political satires Election (1999) and Citizen Ruth (1996), Hal Hartley's postmodern screwball comedies The Unbelievable Truth (1990), Trust (1991) and Henry Fool (1998), post-Pulp Fiction black comedies of violence such as Very Bad Things, Go (Doug Liman 1999) and 2 Days in the Valley (John Herzfeld 1996); Wes Anderson's bittersweet Bottle Rocket (1994), Rushmore (1998) and The Royal Tenenbaums (2001); PT Anderson's operatic odes to the San Fernando valley Magnolia (1998) and Boogie Nights (1997); the 'cold' melodramas of The Ice Storm (Ang Lee 1997), The Sweet Hereafter (Atom Egoyan, Canada 1997) and Safe (Todd Haynes 1995); and the 'matterof-fact' surrealism of Being John Malkovich (Spike Jonze 1999) and Donnie Darko (Richard Kelly 2001)." (350)
} 
existentialism that the characters suffer when they do not know how to respond to the problems entailed by the act of facing a reality they do not understand. In these films, the innocent intuition that leads to sincerity as an escape route is informed by a neo-romantic vision nurtured by the ideas of the American transcendentalist movement (in a manner closely related to Godard's European author cinema). These ideas include childhood and the loss of innocence; 5 the journey as self-discovery; the return to nature; or the search of individualism to find connexion with humanity. Apart from these, one of the most important Emersonian themes-with more ramifications and consequences-can also be found in these films: intuition as a substitute for rationality. These characteristics are diametrically opposed to the tone and content of the scene in Vivre sa vie that we discussed earlier. In the conversation with Parain, Nana understands that thought and language are the same notion, and that you cannot live without communicating through a language. She also learns that error is necessary in order to understand reality. However, to express what one thinks with a language to which referential or essentialist properties are not attributed is to risk lying, or what is the same, not to reach the truth.

In quirky cinema, largely, the characters opt for a transcendentalist mechanism, pure intuitive action, to achieve the authentic, i.e., to create an identity that is coherent and not based on lies. They embrace mistakes. However, not that of language as in postmodernism, but that of experience. In addition, attempts are made not to resort to irony with its multiplicity of levels of meaning.

Another of the elements of American transcendentalism, childhood, is synonymous with sincerity in Emersonian transcendentalism. Ralph Waldo Emerson states in Nature:

\footnotetext{
${ }^{5}$ MacDowell gives an extensive explanation of the methods these films use to create a childlike tone, of which he says: "Like the approaches to comedy and style, then, the theme of childhood (and its thematic bedfellow 'innocence') is finally less essential inand-of itself than for what it allows the films to achieve tonally"(10). Among the methods: "As well as occasionally inspiring the films themselves, drawings comparable to those used in these comics are common in the advertising for quirky movies" (7); "The pitch, repetitiveness, and insistent prettiness of much of this music often lends it a sound and feel reminiscent of the tinkling purity of a child's music box" (8); or the use of medium-shots in which the subjects are in the middle of the composition, which is the type of approach that a child would take when taking a photo, instead of the more mature composition that respects the law of thirds.
} 
The sun illuminates only the eye of the man, but shines into the eye and the heart of the child. The lover of nature is he whose inward and outward senses are still truly adjusted to each other; who has retained the spirit of infancy even into the era of manhood [...] In the woods too, a man casts off his years, as the snake his slough, and at what period so ever of life, is always a child. (1074)

For this reason, many of these films deal with the theme of the passage to adulthood, the loss of innocence (through the acquisition of an adult use of language), the arrival of irony. Travel as selfknowledge is another of the transcendental resources that appear in these works. As a mark of the return to the project of modernity, in these trips an epiphany usually takes place in which the characters understand the essence of their own identity or of their reality without verbalizing it. In this regard, it is important to analyse Magnolia as a story of traumatised children, the source of that trauma being dysfunctional postmodern father figures. Donnie Smith, played by William H. Macy, was an exploited wunderkind; Frank TJ Mackey, played by Tom Cruise, was abandoned by his father when he was a kid and he was forced to take care of her dying mother; Claudia W. Gator, played by Melora Walters, was sexually abused by his father; Stanley Spector, played by Jeremy Blackman, is a boy genius tormented by his tyrannical father's attempt to make him famous.

The effects of relativity, determined by the multiplicity of truths proposed by postmodernity, are reflected in the absence of a clear notion of one's identity that leads to existential problems. This gap is very difficult to fill when the characters in these films do not know the cause of their problems, or the fact that they do not even know they have a problem. Language only fragments the reality they perceive and, therefore, it is only possible to understand it and to configure an identity through intuition. The epiphanies that occur in these films are reached individually and they cannot be explained, on the contrary, they come hand in hand with pure intuitive action-a transcendentalist device-, not linguistic reasoning. This is the reason why silence is a recurring resource in these films (the same silence the Parain speaks about in Vivre sa vie). Emerson explains it in "Self-Reliance": "And now at last the highest truth on this subject remains unsaid; probably cannot be said; for all that we say is the far-off remembering of the intuition" (1135). 


\section{THE LIMINAL POST-POSTMODERNISM OF MAGNOLIA}

Paul Thomas Anderson's Magnolia (1999) deals with themes common to postmodern and post-postmodern cinema from a hybrid perspective. If, as we have argued, Vivre sa vie could be considered one of the central films that open the door to postmodernism, Magnolia might be regarded as its equivalent at the turn of the millennium. The film is a network of individual stories that are interwoven in a complex way to form a larger narrative-reminiscent of metanarratives. All the characters could belong in the category of smart cinema; they have problems of unknown nature. Probably, the smart film where this feature is best seen is Todd Haynes's Safe, also included in the aforementioned article by Sconce. The protagonist, Carol White, suffers from a health problem whose origin is unknown. Carol thinks that the disease is due to toxins in the modern world caused by aerosols, pollution, etc. However, the doctors she visits cannot find an explanation to her illness. The characters in smart films are disoriented people who, without knowing it, are lost seeking a meaning for the world in which they live and their own circumstances. The themes of the film are all common to both smart and quirky cinema: the absence of a functional father figure-as we saw earlier with the review of the traumatized children in Magnolia; the lack of identity; the insufficiency of language to shape an objective reality; the search for speculative knowledge; the temporal correlate between past, present and future; childhood; sincerity; etc. However, chance is probably crucial. Chance is one of the most important agents of the change from modernism to postmodernism and from this last cultural paradigm to something subsequent.

In her thorough-and very helpful-book The MultiProtagonist Film, Maria del Mar Azcona points out the following:

[W]ithin multi-protagonist movies, a trend has emerged as a separate category in critical discourse: those films with no other clear generic affiliations in which the interconnectedness and random crisscrossing of characters with initially independent narrative lines is used to foreground the role that coincidence and accidental encounters play in people's lives.

In this category, she mentions Magnolia, Thirteen Conversations about One Thing (2001), Crash (2004), and Heights (2005). Azcona relates the use of chance in these films to the concept of the butterfly effect and the impossibility of being in total control of 
one's life. All this, she points out, makes us reflect on the connection that individuals share, even if they are not aware of that fact (36).

In Magnolia, the plot is held together by random events that tie all the characters together. This creates a feeling of wonder. One of the differences between this work and smart films-probably the fundamental difference-is its treatment of chance. We should note here that, even though in this analysis we are trying to argue that there is a big difference between Magnolia and smart cinema, Sconce includes this film in his list. Postmodernism, based on the view that coincidences do not respond to complex structures, starts from a scheme of total absence of meaning. By atomizing knowledge, it provokes two simultaneous and opposed-although complementary-reactions. On the one hand, it frees the individual from the historical value of existence, but, on the other, it strips him/her of a coherent and significant relationship with reality. Everything points to the fact that the lives of these people, like those of the protagonists of smart cinema, are intertwined through events that are the result of chance and coincidence. Everything seems to be heading towards the fact that they will not find a logic to the world around them. Suddenly, a deus ex machina occurs. An unexpected heavy rain of frogs shock the audience almost at the end of the film, giving an unanticipated end to all the stories. This resource, which appeals to a superior structure not knowable, is causal and totalizing. Although Anderson seems to be using Godardian techniques to develop a self-referential plot in the service of cinematography, the fact that frogs unexpectedly start to rainwhich fixes almost all episodes through coincidental events-gives this film a very different meaning.

The Godardian self-referential resource of breaking of the fourth wall is used in a different way in Anderson's film. In Vivre sa vie, Nana looks at the camera while listening to the philosopher speak; In Magnolia, Claudia, at the end of the story, looks at the camera smiling hopefully. Although the cinematographic resource is the same, the purposes are opposed. The glance at the camera in the latter case transcends intellectual cinematography to situate itself on the plane of essentialist referentiality. The viewer knows why Claudia is smiling at him/her at the end of the film and shares the hope that the character is feeling; there is no need for language. Anderson uses the knowledge that the postmodern audience has of cinematographic metafiction to break their expectations of where the plot is heading. 
Several subsequent films have dealt with similar themes in a similar way, and quirky cinema takes place only a little later.

Returning to the treatment of chance in this work, Magnolia begins deceiving the viewer. Anderson opens with three anecdotes laden with dramatic irony and filled with dark humour. So far, Magnolia fits the smart cinema paradigm. However, the tone suddenly changes in the first sequence after these three stories: nine characters are introduced while a seven-minute version of Harry Nilsson's song "One," performed by Aimee Mann, plays extradiegetically. The tone is not humorous; it is earnest and dramatic. Apparently, the stories of each of the characters bear no relation to each other. After the introduction with the three ironic stories, suddenly, the audience is watching a completely different film. In a similar fashion to Walt Whitman's "Song of Myself," 6 where the Poet opens with a classic iambic pentameter line and then breaks with that poetic tradition to start writing in free verse, it seems as if Anderson was telling the audience that the time of ironic dark humour was over. After the first six minutes, where the three postmodern chance stories are told, Anderson breaks with the past and starts his three-hour-long movie in a very different key. The beginning of the film resembles its release. Magnolia premiered on the $17^{\text {th }}$ December 1999. It is as if the introduction to the film could fit the remnants of that year; destructive irony dies with the beginning of the year 2000, as it also dies with the beginning of the film, declaring - as the lyrics of the song repeats-that "[o]ne is the loneliest number." It is the time to dispense with loneliness, of the kind of solipsism-provoked by postmodern existentialism-that results in nihilism. For Anderson, it is the time to get in touch honestly and sincerely with the rest of humanity.

The three stories, narrated in off, with which the film begins deal with extremely bizarre chance events with ironically dramatic consequences. Once the three episodes finish, ${ }^{7}$ the narrator concludes:

${ }^{6}$ Ed Folsom indicates this in his foreword to the analysis of Section I of "Song of Myself": "Whitman opens his poem with a conventional iambic pentameter line, as if to suggest the formal openings of the classic epics, before abandoning metrics for a freeflowing line with rhythms that shift and respond to the moment."

7 The first story is about a pharmacist residing in Greenberry Hill, London. He is murdered by three men named Green, Berry, and Hill. In the second story, a 
And it is in the humble opinion of this narrator that this is not just something that happened. This cannot be one of those things. This, please, cannot be that. And for what I would like to say, I can't. This was not just a matter of chance. These strange things happen all the time.

The narrator is hinting at the fact that behind these chance incidents there must be some superior design that makes sense. In Blossoms and Blood: Postmodern Media Culture and the Films of Paul Thomas Anderson (2013), Jason Sperb draws our attention to the coincidental fact that the narrator is the same actor-Ricky Jaywho plays the character of Burt Ramsay, the producer of the TV show What Do Kids Know in the film. As Sperb indicates, it seems as if this character is controlling from above everything that happens in the film. He wears a Freemason ring (Sperb 134), and the symbol of the compass can be seen in the set of the TV programme he produces. The principles of Freemasonry are opposite to those of postmodernism. The symbolism of this institution goes against the narrative fragmentation of history, since its purpose is the search for truth and the understanding of the holistic structure that the Great Architect of the Universe has created. The narrator returns at the end of the film, just after the rain of frogs, as if that deus ex machina episode had been provoked by himself, saying:

There are stories of coincidence and chance, of intersections and strange things told, and which is which and who only knows? And we generally say, "Well, if that was in a movie, I wouldn't believe it." Someone's so-and-so met someone else's so-and-so and so on. And it is in the humble opinion of this narrator that strange things happen all the time. And so it goes, and so it goes. And the book says, "We may be through with the past, but the past ain't through murder with us."

firefighting aircraft collects water from a lake, but it also accidentally takes a diver, who appears dead in of one of the trees in the forest in which the plane had helped put out a fire. The pilot of the plane had assaulted the diver a few days earlier and ends up committing suicide upon learning the news. The third story is about a 17year-old boy who, when trying to commit suicide by jumping off a roof, is killed by a bullet that comes out of a window while falling. The boy himself had loaded the weapon, accidentally fired by his mother during a quarrel with her husband, a few days earlier. The mother is found guilty of homicide and the victim, an accomplice of his own murder. 
This quote brings us to the words of Parain about the errors of the past in Vivre sa vie. Postmodernism and its non-classical vision of chance leaves history without a narrative unity. Magnolia may be read as an attempt to recover that unity by interconnecting a multiplicity of stories, apparently unrelated, of individuals through causality, by returning to the unfinished Habermasian project. The film may also be interpreted as an attempt to re-establish the classic vision of chance: fortuitous events cannot be explained because we do not yet know how to do it, not because there is no reason behind them. This film also tries to recover the modernist approach to history in order to rescue faith in the metanarratives and, thus, to get rid of the crisis-on a large scale and, on a personal levelproduced by relativism and its consequences: existentialism, nihilism and solipsism.

Anderson challenges postmodernism's time focus on the present by appealing to a linear, evolutionary, even organic sense of history. This is reflected in the narrator's last words, "We may be through with the past, but the past ain't through with us." The past is charged with intention, as if it had a will to return. In any case, post-postmodern artists seem to be highlighting the need to recover mistakes to purge the past in an attempt to create a new and coherent identity, that is, to regain an intelligible correspondence with reality (in the sense in which Parain uses the word in Vivre sa vie). This is achieved by ending the postmodern desire to ignore the past and to live in an eternal present that seems not to be the continuation, but something very different from what came beforeas it happens with the non-cumulative paradigms explained by Thomas Kuhn In The Structure of Scientific Revolutions (1970). According to Kuhn, science does not evolve in a linear and gradual way, depositing new advances on top of previous knowledge. Science advances in discrete leaps that break with preceding theories.

We could argue that the founding text of the New Sincerity movement is David Foster Wallace's influential essay " $\mathrm{E}$ Unibus Pluram: Television and U.S. Fiction" (1993). Wallace's influence is evident in Anderson's work in general, but Magnolia takes a leap, similar to the one Wallace took with Infinite Jest (1996), to something beyond postmodernism, to a new realism, through a revival of sincerity and honesty. It is no coincidence that Paul Thomas Anderson was taught by David Foster Wallace at Emerson College, 
Boston. ${ }^{8}$ As we have said, the classical vision of coincidences is neutralized during postmodernity, that is, according to Kuhn's perspective, it is not that science does not have the ability to know what is behind each event in nature. The problem lies in the fact that, even though nature can be deciphered, it does not have a purpose (a grand structure) that needs explanation. During postmodernism, works of fiction were full of coincidences to which either a meaning that is part of a superstructure is not attributed or that meaning is sought through logical reasoning. The two experiences are equally frustrating, since while the second option ends up not giving results, the first one leaves the individual in the midst of an existential and solipsistic crisis. There is a need to find a meaning and accept that there is a connection between two seemingly unrelated events. Such a connection would put the notion of time inside the perspective of the new scientific paradigm. From this vantage, past and present would not be connected linearly, but on different levels and occurring at the same time, conforming to Einstein's scheme. However, this acceptance does not imply that the connection has an ulterior meaning; if we were to accept it, we would be entering the realm of the imaginary, not the real. Paradoxically, the latter assumption of the nature of reality involves its denial, since, if it does not have a complex structure and, thus, meaning, then it is not cognizable, because the only way to eliminate chance is to replace it with a structure of necessity, that is, with a causal structure.

At the beginning of the 21 st Century, informed by the knowledge accumulated during the 20th, individuals are defenceless

\footnotetext{
8 In an interview for Marc Maron's WTF podcast (Episode 565, January 5, 2015), Anderson states: "When I was at Emerson for that year, David Foster Wallace, who was a great writer who was not known then, was my teacher-he was my English teacher ... It was the first teacher I fell in love with. I'd never found anybody else like that at any of the other schools I'd been to. Which makes me really reticent to talk shit about schools or anything else, because it's just like anyplace-if you could find a good teacher, man, I'm sure school would be great." This fragment is taken as published in The Paris Review in Dan Piepenbring's article "When David Foster Wallace Taught Paul Thomas Anderson," January 6, 2015. In the same article, Piepenbring tells us that "[Wallace] was less jazzed about Magnolia, though, which he found pretentious, hollow, and ' $100 \%$ gradschoolish in a bad way."' This is an example that proves what Wallace himself says in "E Unibus Pluram" about the new rebels: they "[r]isk disapproval" (193) because of their innocent boldness to tackle "singleentendres values" (192).
} 
in the face of the crisis, since the only way to end their identity dilemma would be to forget what they had learned during postmodernism. For this reason-although in a certain sceptical way-an attempt is made to believe that there is a plan that, although incomprehensible, underlies coincidences and coincidences in an attempt to recover the lost meaning of a structured reality and a structured identity. That is to say, when trying to make sense of chance events, the perspective suffers a change: logical versus intuitive, that is, reason versus faith.

The beginning of Magnolia brings the viewer closer to the coincidences that occur, for example, in postmodern films, such as Smoke (1995), directed by Wayne Wang and scripted by Paul Auster. In this film, the character played by Harvey Keitel, Auggie Wren, a shop assistant on a tobacconist in Brooklyn, reflects on a casual event with a tragic end. He is not able to find an explanation for the chance death of the wife of one of his regular clients, Paul Benjamin, played by William Hurt. Paul Benjamin is Auster's given name in real life and the pseudonym that the writer used for his first novel, Squeeze Play (1984). She is accidentally killed by a stray bullet from a shooting that takes place just as she leaves the shop. Auggie wonders if the woman would not have died if she had not paid the exact amount that day and it would have taken him a few seconds to return the change. The dramatic irony of the situation, coinciding in place and time with a stray bullet, is reminiscent of the anecdotes from the beginning of Magnolia. The fact is that in Smoke, written and co-directed by Auster (the writer of postmodern chance), this coincidence does not respond to any reason, the characters must learn to accept this fact stoically. The coincidences that occur at the end of Magnolia, on the contrary, open the door to the belief that behind each casual event there is a clue to a larger structure; that things happen-in the words of the narrator-for some reason. This endows reality with linearity, stripping it from postmodernism's focus on the present. From this perspective, coincidences are not folds in space-time, on the contrary, they obey the logic of a scheme that has a beginning and an end; they are closer to a Hegelian conception of history, to a recovery of the belief that reality has a meaning and a structure that can be understood, and, thus, so has individual identity.

This way of considering everything related to coincidences and chance had, after Magnolia, continuity in the cinematographic field. It is not that before this film there were no works with this type 
of plot, but the approach was then very different. In Chapter 7, "Mutual Friends and Chronologies of Chance," from the book Poetics of Cinema (2008), David Bordwell uses the term "network narratives":

This sort of plot pattern has been called 'thread structure', and the films have become known as tales of 'interlocking lives,' 'converging fates,' and 'the web of life.' Variety seems to have settled on 'crisscrossers.' Elsewhere I've called them network narratives, and I'll mostly stick to that here. (191)

He mentions films previous to Magnolia, such as Nashville (1975) and Short Cuts (1993), both by Robert Altman or 71 Fragmente einer Chronologie des Zufalls (1994)—Translated into English as 71 Fragments of a Chronology of Chance-, by Michael Haneke, or Pulp Fiction (1994), by Quentin Tarantino. In the chapter, he gives a list of 150 post-1990 films with this type of structure. They put into perspective the importance of frameworks for culture in a moment of crisis. ${ }^{9}$ Bordwell compares this taste for story imbrication with that of the use of flashbacks in the 1960s: "Converging-fates plots seem to be for us what flashback tales were for the 1960s: the dominant principle of offbeat storytelling" (191).

However, the use of a lattice of stories in cinema responds to a less self-referential desire since Magnolia. The intertwined plots respond to a change of attitude, or-as Vermeulen and van den Akker describe their metamodernism-"a structure of feeling," although this is not Bordwell's position. In an entry in his blog, speaking about Alejandro González Iñárritu's film Babel (2006), he states the following:

Do they reflect some social Zeitgeist? Are we seeking connections with one another? Nope, I don't think so. The most proximate and pertinent causes lie elsewhere [...] Once a formal tradition gets established, artists compete within that, seeking out ways to

\footnotetext{
9 "Such stories have become remarkably common, with nearly 150 films using the network principle released since 1990 [...] In 2005 alone, then appeared Tapas and Sud Express from Spain, Chromophobia and Festival (England), Istanbul Tales (Turkey), Look Both Ways (Australia), Year Zero and What a Wonderful Place (Israel), Who's Camus Anyway? (Japan), Voisins Voisines (France), The Manual of Love (Italy), See You in Space! (Hungary), Frozen Land (Finland), and Crash Test Dummies (Austria). In the same year, filmmakers in the United States gave us Heights, Standing Still, Nine Lives, Happy endings, Loggerheads, American Gun, and Me and You and Everyone We Know." (191)
} 
innovate [...] within tested boundaries. Fresh narrative strategies push the filmmaker to balance the novelty with familiarity.

Bordwell regards the phenomenon of this type of films as a cinematographic device differentiated from modernist experimentation that tries to represent reality. He speaks of it as something completely different from that modernist goal: as a way of complicating the relationship with reality in favour of artistic experimentation, which brings him closer to postmodernism. However, as we have tried to demonstrate, many characteristics indicate the opposite. There is an aspiration to recover the lost realism about which Thomas Wolfe spoke in his influential manifesto about the state of postmodern literature, and the will to end the reign of irony that Wallace crystallised in his article " $E$ Unibus Pluram: Television and US Fiction" (1993). In his 1989 article "Stalking the Billion-Footed Beast," Tom Wolfe spoke about the need to regain a realism in fiction that had been lost with the advancement of postmodernism. In turn, Wallace referred to the need to unseat the reign of irony in the television era through a return to sincerity.

An example of this could be the film Thirteen Conversations about One Thing, directed by Jill Sprecher. ${ }^{10}$ This film opens a year and a half after the one by Paul Thomas Anderson. As in Magnolia, it tells a multiplicity of apparently unrelated stories that end up, by chance, intertwined. At the end of the film, the protagonists attribute meaning to coincidences in a universe in which, as one of the characters-Walker, a university professor of physics-says, "[t]he

\footnotetext{
${ }^{10}$ Azcona offers an ample list of American films that make use of this resource: "Traffic (2000), What's Cooking? (2000), Gosford Park (2001), The Safety of Objects (2001), Sidewalks of New York (2001), Thirteen Conversations About One Thing (2001), Love in the Time of Money (2002), Casa de los Babys (2003), Cape of Good Hope (2004), Crash (2004), Heights (2004), Me and You and Everyone We Know (2005), Babel (2006), Bobby (2006), The Dead Girl (2006), Fast Food Nation (2006), Friends with Money (2006), The Groomsmen (2006), Little Miss Sunshine (2006), Shortbus (2006), Southland Tales (2006), Lions for Lambs (2007), My Blueberry Nights (2007), Vantage Point (2008), The Women (2008), and Crossing Over (2009)" (2). After this list, she goes on to say that "[t]he trend has not been restricted to the USA" (2) and offers another list of films that fit in the scheme: "The Australian Look Both Ways (2005), the Spanish Tapas (2005), the Italian Manuale d'amore (2005), the French-British Chromophobia (2005), the British Festival (2005), the Israeli What a Wonderful Place (2005), the SpanishArgentinian Tocar el cielo (2007), the French-Lebanese Caramel (2007), and the Mexican Cosas Insignificantes (2008)" (2).
} 
laws of the universe are absolute," which makes his solipsism-and the existentialism derived from it-disappear. Both films end with one of the main characters who had lost all hope smiling at the very moment they understand that they are not alone. The connection between the stories indicates the link that unites human beings in a holistic way; it implies that there is a way out of solipsism: being aware of that there are other people who have similar problems.

The lattices of pre-Magnolia films opened up questions about the ineffectiveness of postmodernism for people trying to find an explanation of reality in an age of emptiness. However, those postmodern works drew attention to the failings of authoritarian metanarratives, but they did not provide alternatives. Through the intertwined stories in the films of the first decade of the turn of the century, the viewer's stance changed from an informed audience, superior to the characters' disoriented lives, to an emotional involvement with them. Cynicism disappeared and an innocence, to which viewers were not used during postmodernism, is shared. Wes Anderson's cinema, for example, or Miranda July's, may be too naive for a postmodern audience. This is the risk Wallace talks about in " $\mathrm{E}$ Unibus Pluram" when he announces the nature of the new literary rebels:

The old postmodern insurgents risked the gasp and squeal: shock, disgust, outrage, censorship, accusations of socialism, anarchism, nihilism. The new rebels might be the ones willing to risk the yawn, the rolled eyes, the cool smile, the nudged ribs, the parody of gifted ironists, the "How banal." Accusations of sentimentality, melodrama. Credulity. Willingness to be suckered by a world of lurkers and starers who fear gaze and ridicule above imprisonment without law. (193)

The interweaving of stories in cinema at the turn of the millennium ceases to be a self-referential resource (as Vivre sa vie's self-referential postmodern cinematic experimentation). From that moment, it is used at the service of a new structure of identity and sensibility. This device is connected with the alleviation of that feeling through the dissolution of the individual in a larger network or structure that goes towards a specific objective. Through an intuitive action (reliant on faith)-somewhat out of time due to the scientific advances-, which has a scope that transcends relativism, those networks may give rise to a new meta-narrative capable of 
replacing the Lyotardian grand-narratives of modernity that disappeared during the last half of the 20th century.

Even though quirky cinema flourished during the first decade of the 21 st century and many of those movies used the resource of the multi-character lattice, the production of films with such characteristics started to wane after the financial crisis of 20072008. The intended recovery of a humanistic project of modernity heralded by this liminal post-postmodernism was thwarted by the bank bailout of 2008, which ended in an intensification of the effects of the cultural logic of late capitalism.

\section{WORKS CITED}

AZCONA, María del Mar. The Multi-Protagonist Film. Wiley Blackwell, 2010.

BENJAMIN, Paul. Squeeze Play. Avon Books, 1982.

BORDWELL, David. Poetics of Cinema. Routledge, 2008.

BORDWELL, David. "Lessons from BABEL." David Bordwell's Website on Cinema. 27 November 2006, http://www.davidbordwell.net/blog/2006/11/27/lessons-from-

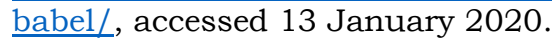

CHAO, Shun-Liang. "(Post)Modern Godard: Vivre sa vie": Synoptique 9 May 2005. Accessed 23 August 2019.

EMERSON, Ralph W. Nature. In The Norton Anthology of American Literature, vol. 1. Edited by Nina Baym et al., Norton, 1998, pp. 1073-1101.

EMERSON, Ralph W. "Self-Reliance." In The Norton Anthology of American Literature, vol. 1. Edited by Nina Baim et al. Norton, 1998, pp. 11261143.

FOLSOM, Ed. Foreword. "Section I, Song of Myself." Whitmanweb, iwp.uiowa.edu/whitmanweb/en/writings/song-of-myself/section-1. Accessed 15 April 2020.

KELLY, Adam. "David Foster Wallace and the New Sincerity in American Fiction." Consider David Foster Wallace: Critical Essays. Edited by David Hering. SSMG Press, 2010, pp. 131-46. 
KELLY, Adam. "David Foster Wallace and New Sincerity Aesthetics: A Reply to Edward Jackson and Joel-Nicholson-Roberts." Orbit: A Journal of American Literature, vol. 5, no.2, 2017. orbit.openlibhums.org/article/id/454/. Accessed 12 February 2020.

KUHN, Thomas. The Structure of Scientific Revolutions. University of Chicago Press, 1970.

LYOTARD, Jean-François. The Postmodern Condition: A Report on Knowledge. Translated by Geoff Bennington and Brian Massumi. Manchester University Press, 1986.

MACDOWELL, James. "Notes on Quirky." Movie: A Journal of Film Criticism, vol. 1, 2010, pp. 1-16.

MANN, Aimee. "One." Magnolia: Music from the Motion Picture, Warner Entertainment, 1999.

PIEPENBRING, Dan. "When David Foster Wallace Taught Paul Thomas Anderson." The Paris Review, 5 Jan. 2015. www.theparisreview.org/blog/2015/01/06/when-david-fosterwallace-taught-paul-thomas-anderson/, Accessed 15 February 2020.

SCONCE, Jeffrey. "Irony, Nihilism and the New American 'smart' Film." Screen, vol. 43, no. 4, 2002, pp. 349-369.

SONTAG, Susan. "Godard's Vivre sa vie." Against Interpretation and Other Essays. Penguin, 2013, pp. 219-232.

SPERB, Jason. Blossoms and Blood: Postmodern Media Culture and the Films of Paul Thomas Anderson. University of Texas Press, 2013.

VERMEULEN, Timotheus, and Robin van den Akker. "Notes on Metamodernism." Journal of Aesthetics \& Culture, vol. 2.0, 2010, https://www.tandfonline.com/doi/full/10.3402/jac.v2i0.5677?scroll= top\&needAccess=true. Accessed 12 January 2020.

WALLACE, David F. "E Unibus Pluram: Television and US Fiction." Review of Contemporary Fiction, vol. 13, no. 2, 1993, pp. 151-194.

WALLACE, David F. Infinite Jest. Back Bay Books, 2006.

WITTGENSTEIN, Ludwig. Tractatus Logico-Philosophicus. The Edinburgh Press, 1922. 
WOLFE, Tom. "Stalking the Billion-Footed Beast." Harper's Magazine, 279, 1989, pp. 45-56.

\section{FILMS CITED}

71 Fragmente einer Chronologie des Zufalls. Directed by Michael Haneke, ZDF, 1994.

Adieu au langage. Directed by Jean-Luc Godard, Wild Bunch, 2014.

Babel. Directed by Alejandro González Iñárritu, Paramount Pictures, 2006.

Crash. Directed by Paul Haggis. Bob Yari Productions, 2004.

Heights. Directed by Chris Terrio. Merchant Ivory Productions, 2005.

Le livre d'image. Directed by Jean-Luc Godard, Casa Azul Films and Ecran Noir Productions, 2018.

Magnolia. Directed by Paul T. Anderson, New Line Cinema, 1999.

Nashville. Directed by Robert Altman, Paramount Pictures, 1975.

Pulp Fiction. Quentin Tarantino, Miramax, 1994.

Safe. Directed by Todd Haynes, American Playhouse Theatrical Films, 1995.

Short Cuts. Directed by Robert Altman, Fine Line Features, 1993.

Smoke. Wayne Wang, Miramax, 1995.

Thirteen Conversations about One Thing. Directed by Jill Sprecher, Stonelock Pictures, 2001.

Vivre sa vie: film en douze tableaux. Directed by Jean-Luc Godard, Les Films de la Pléiade and Pathé Consortium Cinéma, 1962. 